\title{
Degradation of the Selective Herbicide 2,2-Dichloropropionate (Dalapon) by a Soil Bacterium
}

\author{
By ELEANOR K. M. BERRY, N. ALLISON AND A. J. SKINNER \\ Department of Life Sciences, Trent Polytechnic, Nottingham NG1 $4 B U$ \\ AND R. A. COOPER \\ Department of Biochemistry, School of Biological Sciences, \\ University of Leicester, Leicester LE1 7RH
}

(Received 10 May 1978)

\begin{abstract}
A bacterium capable of utilizing the selective herbicide 2,2-dichloropropionate (Dalapon) as sole source of carbon and energy was isolated from soil and tentatively identified as a fast-growing species of Rhizobium. 2-Chloropropionate also supported good growth of the organism but 3-chloropropionate, monochloroacetate and dichloroacetate were not utilized. Bacteria grown in the presence of either 2,2-dichloropropionate or 2-chloropropionate oxidized these compounds and a variety of non-chlorinated substrates but not monochloroacetate.

Cell-free extracts of 2,2-dichloropropionate-grown bacteria converted 2,2-dichloropropionate into pyruvate with the concomitant release of two chloride ions for each molecule of pyruvate formed, indicating the presence of dehalogenase activity. Dichloroacetate and 2-chloropropionate were also inducers and substrates for the dehalogenase. Monochloroacetate was a substrate for the dehalogenase but did not serve as an inducer whereas 3chloropropionate was a non-substrate inducer.
\end{abstract}

\section{INTRODUCTION}

The selective herbicide 2,2-dichloropropionate (Dalapon) is widely used against monocotyledonous plants. It is readily removed from the soil by a variety of micro-organisms including species of Pseudomonas, Agrobacterium, Nocardia, Alcaligenes, Arthrobacter and Bacillus (Foy, 1975). However, the conversion of 2,2-dichloropropionate to intermediates of the central metabolic pathways has not been examined in detail. Bacteria able to utilize 2,2-dichloropropionate are known to release chloride ions from this herbicide (Jensen, 1957, 1960; Hirsch \& Alexander, 1960; Senior et al., 1976) and cell-free extracts of an Arthrobacter species able to grow on 2,2-dichloropropionate have been reported to convert it into pyruvate (Kearney et al., 1964). The present investigation examines some properties of a newly isolated bacterium able to utilize 2,2-dichloropropionate as sole source of carbon and energy. A brief report of part of this work has appeared previously (Berry et al., 1976).

\section{METHODS}

Media. The mineral salts medium was that of Brammar \& Clarke (1964). Sterile solutions of carbon sources were added separately to give a final concentration of $0.5 \%(w / v)$ unless otherwise stated. When a chlorinated aliphatic acid was added as a second carbon source its final concentration was $0.2 \%(\mathrm{w} / \mathrm{v})$ and the final concentration of the non-chlorinated carbon source was reduced to $0 \cdot 4 \%(\mathrm{w} / \mathrm{v})$. Free acids were neutralized to $\mathrm{pH} 7.0$ with $\mathrm{NaOH}$ prior to sterilization by filtration. Media were solidified by the addition of either Oxoid Ionagar no. 2 or Difco Bacto-agar at a final concentration of $1.5 \%(\mathrm{w} / \mathrm{v})$. 
Growth conditions. Bacteria were grown in Universal screw-capped bottles containing either $10 \mathrm{ml}$ nutrient broth or mineral salts medium plus an appropriate carbon source. When larger volumes were required, $100 \mathrm{ml}$ quantities of medium in $250 \mathrm{ml}$ conical flasks were inoculated with $0.2 \mathrm{ml}$ of culture from the corresponding Universal bottle and incubated on an orbital shaker at $250 \mathrm{rev}$. $\mathrm{min}^{-1}$. Bacteria were harvested by centrifugation $(6000 \mathrm{~g}, 10 \mathrm{~min})$. Bacterial dry weight was determined from a standard curve relating the absorbance at $680 \mathrm{~nm}$ to dry weight. All cultures were grown at $30^{\circ} \mathrm{C}$ unless otherwise stated.

Isolation of 2,2-dichloropropionate-utilizing micro-organism. Garden soil (10 g) was added to $50 \mathrm{ml}$ mineral salts medium containing 2,2-dichloropropionate at a final concentration of $0.1 \%(\mathrm{w} / \mathrm{v})$ and incubated at $25{ }^{\circ} \mathrm{C}$. After repeated subculture, an organism capable of utilizing 2,2-dichloropropionate as the sole source of carbon was isolated and purified.

Identification of isolate. Tests were carried out using the methods of Cowan (1974) unless otherwise stated.

Respirometry. Stationary phase bacteria $(100 \mathrm{ml})$ were harvested, washed once with $20 \mathrm{ml} 100 \mathrm{~mm}$ phosphate buffer, $\mathrm{pH} 7 \cdot 2$, and resuspended to give 5 to $10 \mathrm{mg}$ dry wt bacteria $\mathrm{ml}^{-1}$. Oxygen uptake was followed at $30^{\circ} \mathrm{C}$ using a Gilson respirometer. The manometer flasks contained: $0.5 \mathrm{ml}$ cell suspension;

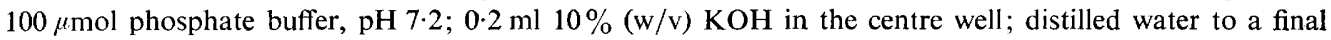
volume of $2.8 \mathrm{ml}$. Substrates $(30 \mu \mathrm{mol}$ in $0.2 \mathrm{ml})$ were added from the side-arm after equilibration. Rates of $\mathrm{O}_{2}$ uptake are expressed as $\mu 1 \mathrm{O}_{2}$ consumed $\mathrm{h}^{-1}(\mathrm{mg} \text { dry } \mathrm{wt})^{-1}$.

Preparation of cell-free extracts. Bacteria were harvested, washed once in $20 \mathrm{ml} 100 \mathrm{~mm}$-phosphate buffer, pH 7.2, and resuspended in $10 \mathrm{ml}$ of the same buffer. Ice-cold cell suspensions were disrupted at $0{ }^{\circ} \mathrm{C}$ by sonication in an MSE disintegrator $(100 \mathrm{~W})$ for $45 \mathrm{~s}$, followed by centrifugation $\left(12000 \mathrm{~g}, 10 \mathrm{~min}, 4^{\circ} \mathrm{C}\right)$. The resulting supernatant solutions, containing 2 to $5 \mathrm{mg}$ crude bacterial protein $\mathrm{ml}^{-1}$, were retained. Soluble protein was estimated by the method of Lowry et al. (1951) using crystalline bovine serum albumin as the standard.

Enzyme assays. The assay for glucose-6-phosphate dehydrogenase [D-glucose-6-phosphate: NADP+ 1-oxidoreductase; EC 1.1.1.49] was based on that of Kuby \& Noltman (1966). The assay mixture contained (in $3 \mathrm{ml}$ ) $: 150 \mu \mathrm{mol}$ Tris $/ \mathrm{HCl}$ buffer, $\mathrm{pH} 8.0 ; 15 \mu \mathrm{mol} \mathrm{MgCl} ; ; 0.75 \mu \mathrm{mol} \mathrm{NADP}$; cell-free extract (containing 530 to $850 \mu \mathrm{g}$ soluble protein). The reaction was started by the addition of $3 \mu$ mol glucose 6 -phosphate to the test cuvette. The reduction of NADP was followed at $340 \mathrm{~nm}$ and $30^{\circ} \mathrm{C}$ using a Pye Unicam SP1800 recording spectrophotometer. In order to assay 6-phosphogluconate dehydrogenase [6-phospho-D-gluconate:NADP ${ }^{+}$2-oxidoreductase (decarboxylating); EC 1.1.1.44], $3 \mu \mathrm{mol}$ 6-phosphogluconate replaced glucose 6-phosphate in the previous assay. For both enzymes, specific activities were calculated as nmol NADP reduced $\min ^{-1}$ (mg protein $)^{-1}$.

Pyruvate estimation. Pyruvate was estimated colorimetrically according to Friedemann \& Haugen (1943), assuming the molar absorption coefficient of alkaline pyruvate 2,4-dinitrophenylhydrazone to be 18000 at $445 \mathrm{~nm}$ (Kornberg \& Morris, 1965). Pyruvate formation from 2,2-dichloropropionate by cell-free extracts was followed continuously at $315 \mathrm{~nm}$ and $30^{\circ} \mathrm{C}$ using a Pye Unicam SP1800 recording spectrophotometer. The assay mixture contained (in $3 \mathrm{ml}$ ): $100 \mu \mathrm{mol}$ 2,2-dichloropropionate; $1.74 \mathrm{mg}$ phenylhydrazine hydrochloride; $0.48 \mathrm{ml}$ RIM buffer. The RIM buffer contained: $200 \mu \mathrm{mol}$ EDTA, pH $6.8 ; 100 \mu \mathrm{mol} \mathrm{MgCl}_{2}$; $500 \mu$ mol imidazole buffer, $\mathrm{pH} 6.8$; distilled water to a final volume of $4 \mathrm{ml}$. The reaction was started by the addition of cell-free extract (containing 50 to $800 \mu \mathrm{g}$ soluble protein) to the test cuvette. Specific activities were calculated as nmol pyruvate formed $\min ^{-1}(\mathrm{mg} \text { protein })^{-1}$, assuming the molar absorption coefficient of pyruvate phenylhydrazone to be 13100 at $315 \mathrm{~nm}$ (Cooper et al., 1965).

Chloride ion estimation. The ability of cell-free extracts of bacteria to release chloride ions from various compounds was followed in an incubation mixture containing $360 \mu \mathrm{mol}$ chlorinated aliphatic acid, $360 \mu \mathrm{mol}$

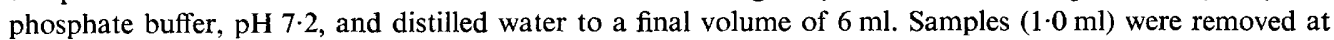
appropriate intervals and assayed for chloride ions, using a Corning EEL (model 920) chloride meter.

Chemicals. 2,2-Dichloropropionate was obtained as the sodium salt from Fluka, CH-9470 Buchs, Switzerland. 2-Chloropropionic and 3-chloropropionic acids were obtained from Ralph N. Emanuel, Wembley. Monochloroacetic and dichloroacetic acids were obtained from BDH. All other chemicals were of the highest purity commercially available.

\section{RESULTS}

\section{Characterization of a 2,2-dichloropropionate-utilizing micro-organism}

The only other chlorinated aliphatic acid to support good growth of the 2,2-dichloropropionate-utilizing organism was 2-chloropropionate. The isolate utilized a number of non-chlorinated compounds as sole source of carbon including pyruvate, lactate, acetate, mannitol, glycerol, glucose, ribose, sucrose and serine. There was little or no growth on 
3-chloropropionate, monochloroacetate, dichloroacetate, citrate, malate, succinate, propionate, glyoxylate, gluconate or acetamide. The doubling time in mineral salts medium with 2,2-dichloropropionate as sole source of carbon was $12.4 \mathrm{~h}$ at $30^{\circ} \mathrm{C}$. The addition of yeast extract at a final concentration of $0.05 \%(\mathrm{w} / \mathrm{v})$ reduced the doubling time with 2,2dichloropropionate to $5 \mathrm{~h}$ at $30^{\circ} \mathrm{C}$. The doubling times in mineral salts medium with pyruvate, lactate and glucose as sole sources of carbon were $3.8,3.5$ and $4.0 \mathrm{~h}$, respectively, at $30{ }^{\circ} \mathrm{C}$. The isolate did not grow at 5 or $37^{\circ} \mathrm{C}$.

The organism was a Gram-negative rod, 0.42 to $0.83 \times 1.7$ to $2.5 \mu \mathrm{m}$ in size when grown in mineral salts medium with 2,2-dichloropropionate or glucose as sole source of carbon. Cells from young cultures were occasionally motile. Colonies, which were 1 to $4 \mathrm{~mm}$ in diameter after $4 \mathrm{~d}$ at $30^{\circ} \mathrm{C}$, had an entire edge, were convex, circular, opaque, shining and white to cream in colour. Older colonies developed a much darker centre. On yeast extract mannitol agar (Fred et al., 1932) copious amounts of free-flowing gum were produced. Congo red (Hahn, 1966) was not absorbed when added to this medium but the addition of $\mathrm{NaCl}$ (Kleczkowska et al., 1968) prevented growth of the isolate. The organism was catalase, oxidase and urease positive but lecithinase, deoxyribonuclease and $\beta$-galactosidase were not produced. An oxidative reaction was given in the medium of Hugh \& Leifson (1953). In the ammonium salt sugar medium of Smith et al. (1952) acid was produced from arabinose, cellobiose, fructose, glucose, glycerol, inositol, maltose, mannitol, sorbitol, sucrose, trehalose and xylose, but not from adonitol, lactose, raffinose, rhamnose, salicin or ethanol. The methyl red and Voges-Proskauer tests were negative. There was no hydrolysis of arginine, aesculin, lysine, ornithine, Tween 20 or 80 . Nitrate was reduced to nitrite but neither indole nor $\mathrm{H}_{2} \mathrm{~S}$ were produced. Gelatin was not liquefied. Gluconate was not converted to 2-ketogluconate and phenylalanine was not converted to phenylpyruvate. Nile blue was not reduced in the medium of Skinner (1977). The organism did not grow on MacConkey agar, in selenite broth or in the presence of either cetrimide or $\mathrm{KCN}$. These results suggest that the 2,2-dichloropropionate-utilizing isolate is a fast-growing species of Rhizobium (Buchanan $\&$ Gibbons, 1974). In support of this view, the isolate was found to possess both glucose-6phosphate dehydrogenase [specific activity $140 \mathrm{nmol}$ NADP reduced $\min ^{-1}(\mathrm{mg} \text { protein })^{-1}$ ] and 6-phosphogluconate dehydrogenase [specific activity $31 \mathrm{nmol}$ NADP reduced $\mathrm{min}^{-1}$ (mg protein $\left.)^{-1}\right]$. This latter enzyme is present in fast-growing but not slow-growing rhizobia, whilst both groups of bacteria possess glucose-6-phosphate dehydrogenase (Martinezde Drets \& Arias, 1972; Mulongoy \& Elkan, 1977).

\section{Oxidation of substrates by bacteria}

Washed suspensions of 2,2-dichloropropionate-grown bacteria readily oxidized 2,2dichloropropionate, pyruvate, lactate and acetate (Table 1). 2-Chloropropionate and alanine were oxidized more rapidly than 2,2-dichloropropionate, after an initial lag period. Propionate and 3-chloropropionate were oxidized less readily than 2,2-dichloropropionate but monochloroacetate, dichloroacetate and propionamide were not oxidized. Bacteria grown on 2-chloropropionate were also able to oxidize 2,2-dichloropropionate. In contrast, washed suspensions of the organism grown on glucose, pyruvate or lactate did not oxidize 2,2-dichloropropionate at a significant rate, although other substrates were readily oxidized by these bacteria (Table 1). Growth on these media in the presence of 2,2-dichloropropionate as a second carbon source enabled the bacteria to oxidize this compound but only at 55 to $79 \%$ of the rate observed for bacteria grown on 2,2-dichloropropionate alone.

\section{Pyruvate formation from 2,2-dichloropropionate by cell-free extracts}

Cell-free extracts prepared from bacteria grown on 2,2-dichloropropionate as sole source of carbon readily converted this compound to pyruvate (Table 2). There was no pyruvate formation when propionate or 2-chloropropionate replaced 2,2-dichloropropionate in the 
Table 1. Oxidation of substrates by bacteria grown on various carbon sources Oxygen uptake was followed at $30^{\circ} \mathrm{C}$ using a Gilson respirometer as described in Methods. Oxygen uptake rates were corrected for endogenous respiration.

Rates of oxidation $\left[\mu 1 \mathrm{O}_{2}\right.$ consumed $\left.\mathrm{h}^{-1}(\mathrm{mg} \text { dry wt })^{-1}\right]$

Substrate

2,2-Dichloropropionate

2-Chloropropionate

3-Chloropropionate

Acetate

Propionate

Pyruvate

Lactate

Glucose

Alanine

2,2-Dichloropropionate

2-Chloropropionate

3-Chloropropionate

Acetate

Propionate

Pyruvate

Lactate

Glucose

Alanine

\section{by bacteria grown on:}

$\begin{array}{cccc}\begin{array}{c}\text { 2,2-Dichloro- } \\ \text { propionate }\end{array} & \begin{array}{c}\text { 2-Chloro- } \\ \text { propionate }\end{array} & \text { Pyruvate } & \begin{array}{c}\text { Pyruvate+ } \\ \text { 2,2-Dichloro- } \\ \text { propionate }\end{array} \\ 18 \cdot 1 & 9 \cdot 3 & 1 \cdot 4 & 12 \cdot 4 \\ 24 \cdot 7 & 28 \cdot 3 & \mathrm{NT} & \mathrm{NT} \\ 3 \cdot 5 & 3 \cdot 1 & \mathrm{NT} & \mathrm{NT} \\ 9 \cdot 5 & 29 \cdot 1 & 34 \cdot 8 & 15 \cdot 8 \\ 4 \cdot 5 & 16 \cdot 6 & \mathrm{NT} & \mathrm{NT} \\ 10 \cdot 3 & 9 \cdot 9 & 12 \cdot 6 & 34 \cdot 5 \\ 10 \cdot 9 & 3 \cdot 8 & 22 \cdot 2 & 16 \cdot 2 \\ 0 \cdot 9 & 1 \cdot 5 & 3 \cdot 5 & 1.7 \\ 25 \cdot 5 & 65 \cdot 2 & 34 \cdot 4 & 41 \cdot 4\end{array}$

Lactate + 2,2-Dichloro-

Lactate propionate

Glucose

Glucose +

2,2-Dichloro-

$$
14 \cdot 3
$$

NT

NT

$30 \cdot 6$

NT

NT

NT

$10 \cdot 9$

NT

$18 \cdot 7$

$22 \cdot 4$

$1 \cdot 6$

$25 \cdot 6$

$0 \cdot 4$
NT
NT
$13 \cdot 3$
NT
-
$3 \cdot 3$
$22 \cdot 5$
$22 \cdot 8$
propionate
$9 \cdot 9$

NT

NT

$11 \cdot 3$

NT

$12 \cdot 0$

$11 \cdot 3$

$6 \cdot 3$

$19 \cdot 7$

-, No net $\mathrm{O}_{2}$ uptake; NT, not tested.

Table 2. Pyruvate formation from 2,2-dichloropropionate by cell-free extracts of bacteria grown on various carbon sources

Carbon source(s) for growth

2,2-Dichloropropionate

2-Chloropropionate

Lactate

Lactate + 2,2-dichloropropionate

Pyruvate

Pyruvate $+2,2$-dichloropropionate

Mannitol

Mannitol+2,2-dichloropropionate

Glycerol

Glycerol +2,2-dichloropropionate

Glucose

Glucose + 2,2-dichloropropionate

Lactate +2 -chloropropionate

Lactate +3 -chloropropionate

Lactate + dichloroacetate

Lactate + monochloroacetate

$\begin{gathered}\text { Pyruvate } \\ \text { formed } \\ \text { [nmol min }\end{gathered}$
(mg protein $)^{-1}$ ]
$64 \cdot 4$
$10 \cdot 3$
$\mathrm{ND}$
$35 \cdot 9$
$\mathrm{ND}$
$16 \cdot 0$
$\mathrm{ND}$
$17 \cdot 9$
$\mathrm{ND}$
$23 \cdot 7$
$\mathrm{ND}$
$22 \cdot 2$
$11 \cdot 1$
$10 \cdot 4$
$21 \cdot 4$
$\mathrm{ND}$

ND, Not detectable. 
Table 3. Chloride ion release from chlorinated aliphatic acids by cell-free extracts of 2,2-dichloropropionate-grown bacteria

\begin{tabular}{|c|c|}
\hline Substrate & $\begin{array}{l}\text { Chloride ion } \\
\text { released } \\
{\left[\text { nmol min }{ }^{-1}\right.} \\
\left.(\text { mg protein })^{-1}\right]\end{array}$ \\
\hline 2,2-Dichloropropionate & 129 \\
\hline 2-Chloropropionate & 419 \\
\hline 3-Chloropropionate & ND \\
\hline Monochloroacetate & 335 \\
\hline Dichloroacetate & 76 \\
\hline
\end{tabular}

incubation mixture. Extracts of bacteria grown on 2-chloropropionate were also able to convert 2,2-dichloropropionate to pyruvate but only at one-sixth of the rate observed using extracts of 2,2-dichloropropionate-grown cells (Table 2). Extracts of bacteria grown on lactate, pyruvate, mannitol, glycerol and glucose did not form pyruvate from 2,2-dichloropropionate. However, growth on these non-chlorinated compounds in the presence of 2,2-dichloropropionate resulted in induction of the pyruvate-forming system (Table 2).

Some chlorinated aliphatic acids, which did not support growth, nevertheless induced the pyruvate-forming system when added to bacteria growing on lactate as the sole carbon source. Extracts prepared from cells grown on lactate in the presence of dichloroacetate converted 2,2-dichloropropionate to pyruvate at twice the rate observed using extracts of cells grown on lactate in the presence of either of the monochloropropionates (Table 2). However, monochloroacetate did not induce the pyruvate-forming system.

\section{Chloride ion release by cell-free extracts}

The liberation of chloride ions from 2,2-dichloropropionate would be expected to accompany the formation of pyruvate from 2,2-dichloropropionate. Cell-free extracts of bacteria grown on 2,2-dichloropropionate as sole source of carbon readily liberated chloride ions from this compound when added to an incubation mixture containing only $60 \mathrm{~mm}$-phosphate

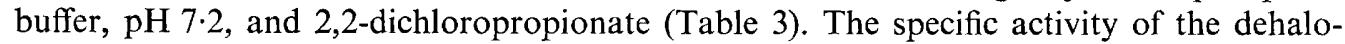
genase was $129 \mathrm{nmol}$ chloride ion released $\min ^{-1}(\mathrm{mg} \text { protein })^{-1}$. When samples of the incubation mixture were assayed for both chloride ion and pyruvate (Friedemann \& Haugen, 1943), one molecule of the latter compound was present for each two chloride ions.

Chloride ions were also released from other chlorinated aliphatic acids (Table 3). The rate with 2-chloropropionate was about three times that with 2,2-dichloropropionate but there was no chloride ion release from 3-chloropropionate. Although monochloroacetate was not oxidized by whole bacteria, chloride ions were released from this compound more rapidly than from 2,2-dichloropropionate. Chloride ions were also liberated from dichloroacetate but at about half the rate observed for 2,2-dichloropropionate. The Michaelis constants for 2,2-dichloropropionate, 2-chloropropionate, monochloroacetate and dichloroacetate were $1.95,3 \cdot 8,16 \cdot 4$ and $1.69 \mathrm{~mm}$, respectively.

\section{DISCUSSION}

The results of a number of identification tests, together with the comparatively rapid growth rate of the 2,2-dichloropropionate-utilizing bacterium, indicate that this organism is a fast-growing species of Rhizobium. The presence of 6-phosphogluconate dehydrogenase in the isolate adds weight to this conclusion as this enzyme is present in fast-growing but not slow-growing rhizobia (Martinez-de Drets \& Arias, 1972; Mulongoy \& Elkan, 1977). 
Species of Rhizobium have not previously been reported to degrade 2,2-dichloropropionate but these bacteria are known to utilize a wide range of carbon sources for growth (Buchanan \& Gibbons, 1974). At least some species are closely related to pseudomonads and agrobacteria (Elkan, 1971; White, 1972), which have been reported to grow on 2,2-dichloropropionate (Jensen, 1957, 1960; Magee \& Colmer, 1959; Senior et al., 1976).

The formation of pyruvate from 2,2-dichloropropionate by extracts of bacteria grown on this latter compound as sole source of carbon was readily demonstrable in agreement with the observation of Kearney et al. (1964). As two chloride ions were released from 2,2-dichloropropionate for each molecule of pyruvate formed, the conversion of 2,2dichloropropionate to pyruvate may be taken as a measure of dehalogenase activity in this bacterium. 2-Chloropropionate, 3-chloropropionate and dichloroacetate served as inducers of dehalogenase activity but were not as effective as 2,2-dichloropropionate under the same conditions. 2-Chloropropionate is also an inducer of the dehalogenase from Pseudomonas putida $\mathrm{P} 3$ (Slater et al., 1976), but the inducer specificity of the dehalogenase from an Arthrobacter species was not examined by Kearney et al. (1964).

Studies on the substrate specificities of dehalogenases from 2,2-dichloropropionateutilizing micro-organisms are confined to the brief reports by Kearney et al. (1964) and Slater et al. (1976). In the present study it was found that chloride ions were liberated from 2-chloropropionate more readily than from 2,2-dichloropropionate, which could account for the more rapid oxidation of the former compound by whole cells. As two chloride ions are released from 2,2-dichloropropionate compared with one from 2-chloropropionate, this latter compound is effectively dehalogenated 6.5 times more readily than 2,2-dichloropropionate. In contrast, the partially purified dehalogenase from an Arthrobacter species liberated chloride ions from 2-chloropropionate less readily than from 2,2-dichloropropionate (Kearney et al., 1964). The dehalogenase from $P$. putida $\mathrm{P} 3$ also showed activity towards 2-chloropropionate but the relative rates of chloride ion release from this compound and 2,2-dichloropropionate were not reported (Slater et al., 1976).

Dichloroacetate and monochloroacetate were also substrates for the dehalogenase but did not support growth of the isolate. In the case of dichloroacetate this may be due to the inability of the organism to utilize glyoxylate which is formed from dichloroacetate (Goldman, 1972). The inability of monochloroacetate to induce the dehalogenase is one explanation for the observed lack of growth on this chlorinated compound. Dichloroacetate was a substrate for the dehalogenase from an Arthrobacter species (Kearney et al., 1964) but no activity was reported with monochloroacetate. The corresponding enzyme from $P$. putida P3 possessed activity towards dichloroacetate and monochloroacetate (Slater et al., 1976). Although 3-chloropropionate induced the dehalogenase it was not a substrate for the enzyme. The dehalogenase from Arthrobacter also showed no activity with 3-chloropropionate (Kearney et al., 1964) whereas the enzyme from $P$. putida showed slight activity towards this substrate (Slater et al., 1976).

The present study has shown that a species of Rhizobium capable of growth on 2,2dichloropropionate can readily convert this substance to pyruvate by means of an inducible dehalogenase. This enzyme shows activity with a variety of chlorinated aliphatic acids and can be induced not only by 2,2-dichloropropionate but also by other chlorinated compounds. Additional information on the properties of the enzymes from cells grown under various conditions will lead to a greater understanding of the degradation of 2,2-dichloropropionate and related compounds.

We gratefully acknowledge the valuable contributions of $\mathrm{Mr} \mathrm{B}$. Holmes of the Central Public Health Laboratory, London, and Dr K. Feltham of the University of Leicester in performing some tests used in the identification of the isolate. We thank Mrs E. Parkin for help in the isolation of the 2,2-dichloropropionate-utilizing micro-organism. 


\section{REFERENCES}

Berry, E. K. M., Skinner, A. J. \& Cooper, R. A. (1976). The bacterial degradation of 'Dalapon'. Proceedings of the Society for General Microbiology 4. 38-39.

Brammar, W. J. \& Clarke, P. H. (1964). Induction and repression of Pseudomonas aeruginosa amidase. Journal of General Microbiology 37, 307-319.

Buchanan, R. E. \& Gibbons, N. E. (editors) (1974). Bergey's Manual of Determinative Bacteriology, 8th edn. Baltimore: Williams \& Wilkins.

CoOper, R. A., Itiaba, K. \& KornberG, H. L. (1965). The utilization of aconate and itaconate by Micrococcus sp. Biochemical Journal 94, 25-31.

Cowan, S. T. (1974). Manual for the Identification of Medical Bacteria, 2nd edn. Cambridge: Cambridge University Press.

ELKAN, G. H. (1971). Biochemical and genetical aspects of the taxonomy of Rhizobium japonicum. Plant and Soil, special volume, 85-104.

Foy, C. L. (1975). The chlorinated aliphatic acids. In Herbicides. Chemistry, Degradation and Mode of Action, vol. 1, pp. 399-452. Edited by P. C. Kearney \& D. D. Kaufman. New York: Marcel Dekker.

Fred, E. B., Baldwin, I. L. \& McCoy, E. (1932). Root Nodule Bacteria and Leguminous Plants. Madison: University of Wisconsin Press.

FriedemanN, T. E. \& HaUGeN, G. H. (1943). Pyruvic acid. II. The determination of keto acids in blood and urine. Journal of Biological Chemistry 147, 415-422.

Goldman, P. (1972). Enzymology of carbonhalogen bonds. In Degradation of Synthetic Organic Molecules in the Biosphere, pp. 147-165. Washington, D.C.: National Academy of Sciences.

HAHN, N. J. (1966). The Congo red reaction in bacteria and its usefulness in the identification of rhizobia. Canadian Journal of Microbiology 12, 725-733.

Hirsch, P. \& AleXANDER, M. (1960). Microbial degradation of halogenated propionic and acetic acids. Canadian Journal of Microbiology 6, 241249.

Hugh, R. \& Leifson E. (1953). The taxonomic significance of fermentative versus oxidative metabolism of carbohydrates by various Gramnegative bacteria. Journal of Bacteriology 66, 24-26.

JENSEN, H. L. (1957). Decomposition of chlorosubstituted aliphatic acids by soil bacteria. Canadian Journal of Microbiology 3, 151-164.

JENSEN, H. L. (1960). Decomposition of chloroacetates and chloropropionates by bacteria. Acta agriculturae scandinavica 10, 83-103.
Kearney, P. C., Kaufman, D. D. \& Beall, M. L. (1964). Enzymatic dehalogenation of 2,2-dichloropropionate. Biochemical and Biophysical Research Communications 14, 29-33.

Kieczkowska, J., Nưtman, P. S., Skinner, F. A. \& VINCENT, J. M. (1968). The identification and classification of Rhizobium. In Identification Methods for Microbiologists, part B, pp. 51-65. Edited by B. M. Gibbs \& D. A. Shapton. London and New York: Academic Press.

KornberG, H. L. \& Morris, J. G. (1965). The utilization of glycollate by Micrococcus denitrificans: the $\beta$-hydroxyaspartate pathway. Biochemical Journal 95, 577-586.

Kuby, S. A. \& Noltman, E. A. (1966). Glucose-6phosphate dehydrogenase (crystalline) from brewer's yeast. Methods in Enzymology IX, 116125.

Lowry, O. H., Rosebrough, N. J., Farr, A. L. \& Randall, R.J. (1951). Protein measurement with the Folin phenol reagent. Journal of Biological Chemistry 193, 265-275.

Magee, L. A. \& Colmer, A. R. (1959). Decomposition of 2,2-dichloropropionic acid by soil bacteria. Canadian Journal of Microbiology 5, 255-260.

Martinez-de Drets, G. \& Arias, A. (1972). Enzymatic basis for differentiation of Rhizobium into fast- and slow-growing groups. Journal of Bacteriology 109, 467-470.

MulongoY, K. \& ElKAN, G. H. (1977). The role of 6-phosphogluconate dehydrogenase in Rhizobium. Canadian Journal of Microbiology 23, 12931298.

Senior, E., Bull, A. T. \& Slater, J. H. (1976). Enzyme evolution in a microbial community growing on the herbicide Dalapon. Nature, London 263, 476-479.

Skinner, F. A. (1977). An evaluation of the Nile Blue test for differentiating rhizobia from agrobacteria. Journal of Applied Bacteriology 43, 9198.

Slater, J. H., Weightman, A. J., Senior, E. \& Bull, A. T. (1976). The dehalogenase from Pseudomonas putida. Proceedings of the Society for General Microbiology 4, 39-40.

Smith, R. N., Gordon, R. E. \& Clarke, F. E. (1952). Aerobic Sporeforming Bacteria, Agriculture Monograph no. 16. Washington, D.C.: U.S. Department of Agriculture.

White, L. O. (1972). The taxonomy of the crowngall organism Agrobacterium tumefaciens and its relationship to rhizobia and other agrobacteria. Journal of General Microbiology 72, 565-574. 